\title{
Front Matter: Volume 12030
}

, "Front Matter: Volume 12030," Proc. SPIE 12030, Third International Conference on Optoelectronic Science and Materials (ICOSM 2021), 1203001 (9 December 2021); doi: 10.1117/12.2622856

SPIE Event: Third International Conference on Optoelectronic Science and SPIE. Materials (ICOSM 2021), 2021, Hefei, China 


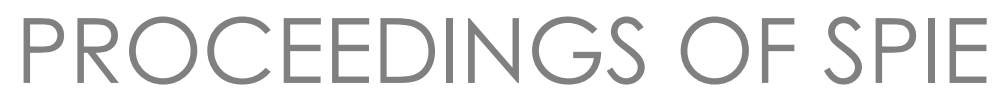

\title{
Third International Conference on Optoelectronic Science and Materials (ICOSM 2021)
}

\author{
Pei Wang \\ Siting Chen \\ Editors \\ 10-12 September 2021 \\ Hefei, China \\ Organized by \\ Key Laboratory of Infrared and Low Temperature Plasma in Anhui Province (China) \\ Sponsored by \\ National University of Defense Technology (China) \\ University of Science and Technology of China \\ AEIC-Academic Exchange Information Centre (China) \\ Published by \\ SPIE
}

Volume 12030 
The papers in this volume were part of the technical conference cited on the cover and title page. Papers were selected and subject to review by the editors and conference program committee. Some conference presentations may not be available for publication. Additional papers and presentation recordings may be available online in the SPIE Digital Library at SPIEDigitalLibrary.org.

The papers reflect the work and thoughts of the authors and are published herein as submitted. The publisher is not responsible for the validity of the information or for any outcomes resulting from reliance thereon.

Please use the following format to cite material from these proceedings:

Author(s), "Title of Paper," in Third International Conference on Optoelectronic Science and Materials (ICOSM 2021), edited by Pei Wang, Siting Chen, Proc. of SPIE 12030, Seven-digit Article CID Number (DD/MM/YYYY); (DOI URL).

ISSN: 0277-786X

ISSN: 1996-756X (electronic)

ISBN: 9781510649316

ISBN: 9781510649323 (electronic)

Published by

SPIE

P.O. Box 10, Bellingham, Washington 98227-0010 USA

Telephone +1 3606763290 (Pacific Time)

SPIE.org

Copyright (C) 2021 Society of Photo-Optical Instrumentation Engineers (SPIE).

Copying of material in this book for internal or personal use, or for the internal or personal use of specific clients, beyond the fair use provisions granted by the U.S. Copyright Law is authorized by SPIE subject to payment of fees. To obtain permission to use and share articles in this volume, visit Copyright Clearance Center at copyright.com. Other copying for republication, resale, advertising or promotion, or any form of systematic or multiple reproduction of any material in this book is prohibited except with permission in writing from the publisher.

Printed in the United States of America by Curran Associates, Inc., under license from SPIE.

Publication of record for individual papers is online in the SPIE Digital Library.

\section{SPIE. DIGITAL}

Paper Numbering: A unique citation identifier (CID) number is assigned to each article in the Proceedings of SPIE at the time of publication. Utilization of CIDs allows articles to be fully citable as soon as they are published online, and connects the same identifier to all online and print versions of the publication. SPIE uses a seven-digit CID article numbering system structured as follows:

- The first five digits correspond to the SPIE volume number.

- The last two digits indicate publication order within the volume using a Base 36 numbering system employing both numerals and letters. These two-number sets start with 00, 01, 02, 03, 04, 05, 06, 07, 08, 09, 0A, OB ... 0Z, followed by 10-1Z, 20-2Z, etc. The CID Number appears on each page of the manuscript. 


\section{Contents}

RESEARCH ON THE PERFORMANCE OF OPTOELECTRONIC FUNCTIONAL MATERIALS AND DEVICES

1203002 Development of narrow linewidth distribution feedback fiber laser for fiber hydrophone system [12030-15]

$1203003 \quad$ Low loss ultra-smooth gold films for two-dimensional material plasmonic devices [12030-32]

1203004 Research on test system architecture of electro-optical countermeasure equipment support [12030-35]

1203005 Time delay remaining in the displacement detection of the optically trapped particles using Kalman filter [12030-13]

1203006 Research on the algorithm of solving the optical axis direction of celestial navigation star sensor [12030-8]

1203007 Development and application of conversion from highly argillized and extremely difficult separate raw coal to coking coal [12030-1]

1203008 Luminescent properties of $\mathrm{Ce}^{3+}$ doped and $\mathrm{Ce}^{3+} / \mathrm{Mn}^{2+}$ co-doped $3 \mathrm{CaO}_{-} \mathrm{CaF}_{2}-2 \mathrm{SiO}_{2}$ glasses $^{2}$ [12030-29]

1203009 Different doping of biomass-derived carbon dots effect on the degradation efficiency of methylene blue [12030-4]

12030 OA Effect of alkaline environment on $\mathrm{Ti}_{3} \mathrm{C}_{2} \mathrm{~T}_{\mathbf{x}}-\mathbf{M X e n e}$ etching [12030-12]

12030 OB High impact resistant missile laser [12030-42]

12030 OC Research progress on synthesis and properties of eco-friendly insulation medium $\mathrm{C}_{5} \mathrm{~F}_{10} \mathrm{O}$ [12030-48]

12030 OD Influence factors and current response of carbon cloth bipolar plate electro-enhanced bioreactor (CBEEB) for nitrogen removal [12030-50]

12030 OE Photocatalytic performance and mechanism of $\mathrm{BP} / \mathrm{Bi}_{2} \mathrm{MoO}_{6}$ powder material with direct Z-type hetero-junction [12030-78]

12030 OF Effects of ultra-freezing/thawing cycles on the mechanical properties and microstructure of Shanghai clay [12030-68]

12030 OG Real-time wavelength compensation of laser diode interferometer [12030-84]

$12030 \mathrm{OH} \quad$ Enzyme inhibition-based electrochemical biosensors for pesticide residues detection [12030-41] 
$12030 \mathrm{Ol} \quad$ Advances in colorimetric biosensors for antibiotics detection [12030-37]

$12030 \mathrm{~J} \mathrm{~J} \quad$ Exploring the synthesis of $\mathrm{MoS}_{2}$-based composite nanoelectrode materials for hydrogen production from electrolysis of water [12030-21]

12030 OK Graphdiyne as catalyst-support for electrocatalytic water splitting [12030-43]

$12030 \mathrm{OL} \quad$ The technology of ion beam etching at extreme-low temperature used in preparing HgCdTe photoconductive devices [12030-9]

12030 OM Study on the effect of ball milling process on the absorption properties of carbonyl iron powder [12030-34]

12030 ON Research progress on optical biosensors for pathogenic bacteria detection [12030-40]

1203000 Metamaterial optical antennas powered carbon nanotube detectors with extremely high polarization selectivity [12030-23]

12030 OP Impact of opening ratio on seismic performance of light-gauge steel structure [12030-94]

$120300 Q \quad$ Investigation on low-temperature performance of reclaimed asphalt pavement binder through bending beam rheometer test [12030-89]

12030 OR First principles study on the structures and properties of aluminum under high pressures [12030-60]

12030 OS Evaluation of performance of recycled reclaimed asphalt pavement (RAP) [12030-91]

12030 OT Mechanical properties and microstructure of reactive powder concrete with multi-walled carbon nanotubes [12030-53]

12030 OU Type-II heterostructure based on two-dimensional arsenene and PtS 2 with novel light absorption performance [12030-87]

12030 OV Preparation and characterization of CdTe low concentrator solar cells [12030-54]

12030 OW Research on fire resistance performance of substation building wall [12030-76]

12030 OY Study on the characteristics of the new type of plastic water glass gel fire prevention and fire extinguishing material [12030-93]

\section{OPTICAL INFORMATION PROCESSING TECHNOLOGY AND INFRARED TECHNOLOGY}

$120300 Z \quad$ Noise analysis of optical satellite infrared detection system [12030-14]

$1203010 \quad$ Refinement principle and technology of Ti-Al base alloy [12030-3] 
1203011 A vehicle angular motion isolation method for dual-axis rotational laser gyro inertial navigation system [12030-7]

1203012 Discussion of the nano electromechanical switch [12030-39]

1203013 Research on evaluation of investment benefits of photovoltaic power generation projects considering environmental benefits [12030-47]

1203014 Optimal design and experimental research of photovoltaic bracket foundation in karst area [12030-81]

1203015 A design method applied to civil commercial aircraft cabin laser projection system based on system engineering thoughts [12030-17]

1203016 Experiments and numerical simulation of thermal effect of the xenon lamp on the cottonpadded jacket [12030-27]

$1203017 \quad$ Narrowband tunable graphene perfect absorber based on dielectric microcavity in midinfrared [12030-20]

1203018 Research on infrared stealth methods for thermal target during sun exposure [12030-33]

1203019 Research and application of infrared technology in temperature monitoring and early warning of hazardous goods in port container yard [12030-19]

120301 A Relationship between reflectivity and traveling wave suppression [12030-11]

12030 1B Design and its electromagnetic properties of low emissivity selective radiators in middle and far infrared bands [12030-26]

$120301 \mathrm{C}$ Analysis of bearing characteristics of composite sandwich cylindrical shell under hydrostatic pressure [12030-24]

12030 1D Multi-impurities induced crystallization for fused silica glasses upon heating by contact with the corundum plate [12030-16]

$12030 \mathrm{lE} \quad$ Analysis of landing position of explosively formed projectile under the decoy jamming of terminal-sensitive projectile [12030-18]

$12030 \mathrm{IF}$ Influence of existing shield tunnels on the stability of adjacent slurry trench [12030-49]

12030 1G Preparation of iron-loaded fly ash and study on Fenton catalytic oxidation of p-Clorophenol [12030-65]

$120301 \mathrm{H}$ Cost analysis of prefabricated concrete structure and cast-in-place structure [12030-79]

$1203011 \quad$ Discussion on lode angle in advanced soil mechanics [12030-74]

$12030 \mathrm{lJ} \quad$ Experiment study on bearing capacity of large-diameter long pile in large thickness backfill loess site [12030-58] 
12030 1K Development and evaluation of environment friendly viscosity reducer for high temperature and high density drilling fluid [12030-71]

$120301 \mathrm{~L} \quad$ Model construction for the formation mechanism of Fatamoogana Mirage [12030-36]

$120301 \mathrm{M} \quad$ Study on the process of separating electrolyte from aluminum electrolytic spent carbon anode by flotation [12030-77]

12030 IN Coking characteristics of oily sludge pyrolysis [12030-66]

1203010 Study of synergistic treatment of oil sludge by coal-fired power plant [12030-51]

12030 1P Analysis of environmental factors of PM2.5 concentration in China based on feature selection and label construction [12030-55]

$120301 Q \quad$ Carbon emission path clusters: emission profiling to identify anomalies in carbon emission paths [12030-99]

12030 IR Greenhouse gas emissions associated with electric vehicle adoption: the environmental impact of EVs development in Hong Kong [12030-97]

12030 is Analysis on microbiological characteristics of low temperature wastewater treated by segmented inlet AO process [12030-64]

12030 IT Application of a highly efficient and environmentally friendly flame retardant for soft cotton fabrics [12030-57]

$120301 \mathrm{U} \quad$ Crystal structure of Mn-based MOF as a new catalyst for synthesizing novel insecticide tetrachlorantraniliprole [12030-75]

$120301 \mathrm{~V} \quad$ Analysis of physical property fitting and variation law of associated gas containing light hydrocarbon in $\mathrm{CO}_{2}$ flooding [12030-67]

$120301 \mathrm{~W}$ Investigation of the association of black carbon and PM1 with planetary boundary layer in China [12030-72]

12030 1X Causes and processing methods for quality defects of CFG piles at high compressibility soft soil site [12030-69]

$120301 Y \quad$ Summary of research status of phase change concrete [12030-80]

OPTICAL SIGNAL DETECTION AND REMOTE SENSING IMAGE PROCESSING

$1203012 \quad$ Research on comprehensive monitoring and dynamic evaluation model of three-span line condition based on all-optical sensing [12030-5]

1203020 Traceable modeling and measurement method for characteristic parameters of optical fiber end face [12030-6] 
$1203021 \quad$ Study on rapid detection of food deterioration based on laser absorption spectroscopy [12030-28]

1203022 Finite element simulation of seepage thermal monitoring of earth-rock dam based on COMSOL [12030-38]

$1203023 \quad$ Numerical simulation analysis of stress and strain of titanium alloy thick plate ultra-narrow gap welded joint by laser welding with filler wire [12030-2]

$1203024 \quad$ Single station positioning of identification friend or foe signal [12030-22]

$1203025 \quad$ Study on deformation characteristics of excavation of super-deep working well pit along the Yellow River [12030-73]

1203026 Study on characteristic identification of solid wastes of recycled PVC plastic products [12030-61]

1203027 Dynamic response analysis of cantilever retaining wall under earthquake [12030-59]

1203028 Investigation on design of hot in-plant recycled asphalt mixtures [12030-92]

1203029 Adhesive force and adhesion energy of particle-substrate detachment [12030-56]

12030 2A Determination of polyurethane content in modified polyoxymethylene by nuclear magnetic resonance spectroscopy [12030-62]

12030 2B Simulation study on radioactive deposition of nuclear explosion taking Trinity test as an example [12030-52]

12030 2C Feasibility on characterizing earth-like planets by their optical variation [12030-45]

12030 2D Interpretation of AMS-02 positrons data with secondary production and pulsars [12030-46]

$120302 \mathrm{E} \quad$ The cracking analysis of refined oil pipeline elbow [12030-90]

$120302 \mathrm{~F} \quad$ Analysis of burning probability and molten mark characteristics of wires after short circuit induced by overcurrent [12030-98]

$120302 \mathrm{G}$ The light-music association investigation based on physiological responses and emotional ratings [12030-30]

$120302 \mathrm{H} \quad$ Research progress of phosphorus-based catalysts in OER and HER [12030-86]

$1203021 \quad$ Experimental research on explosion pressure of the deposited flour induced by shock wave [12030-88]

$120302 \mathrm{~J} \quad$ Time series characteristics and difference analysis of AE of coal deformation and fracture under different damage and failure conditions [12030-96] 
$120302 \mathrm{~K} \quad$ Research and comprehensive analysis on fire extinguishing of LiFePO 4 battery [12030-85]

12030 2L Can HIT batteries replace PERC batteries as the new direction of development? [12030-100]

$120302 \mathrm{M}$ Dense three-dimensional point continuous measurement based on triple line-scan cameras [12030-31]

$120302 \mathrm{~N} \quad$ Experimental research on the influence of glass spacing on digital image correlation in measuring optical path [12030-83]

1203020 Analysis of effects of retroreflector motion errors on measurement accuracy of a homodyne interferometer [12030-82] 